\title{
Kastamonu İli Fındıklı Yaylasında Küresel İklim Değişikliğine Bağlı Olarak Meydana Gelebilecek İklim Tipi Değişiklikleri
}

\author{
Ezgi GÜR ${ }^{1}$, Şahin PALTA ${ }^{2 *}$ \\ ${ }^{1}$ Bartın Üniversitesi, Lisansüstü Eğitim Enstitüsü, Orman Mühendisliği Anabilim Dalı, 74100, Bartın \\ ${ }^{2 *}$ Bartın Üniversitesi, Orman Fakültesi, Orman Mühendisliği Bölümü, 74100, Bartın
}

\section{Öz}

Bütün dünyada canlılar ve ekosistemler için iklim çok önemli bir unsurdur. İklimin dünya üzerindeki olumlu veya olumsuz etkisinin insanları doğrudan veya dolaylı olarak etkilediği bilinmektedir. Bu süreçte iklim parametreleri ve iklim tiplerinde meydana gelecek değişikliklerin önceden belirlenmesiyle, alınabilecek tedbirler ve sürece hazırlıklı olunması bakımından büyük önem taşımaktadır. Çalışmamızda RCP (Representative Concentration Pathways -Temsili Konsantrasyon Yolu) senaryolarından, genellikle akademik çalışmalarda kullanılan RCP 4.5 ve RCP 8.5 senaryoları baz alınmıştır. De Martone, Emberger ve Lang iklim sınıfları kullanılmış ve bu iklim sınıflarına göre iklim tipleri günümüz, 2050 yılı ve 2100 yılı için değerlendirilmiş ve aralarında karşılaştırmalar yapılmış, böylece sıcaklık, yağış ve bunlara bağlı olarak iklimin süreç içerisinde nasıl değişeceği tahmin edilmeye çalışılmıştır. Çalışmada ülkemizin önemli şehirlerinden biri olan Kastamonu ili Araç ilçesine bağlı Fındıklı yaylasında 2050 ve 2100 yıllarına kadar, sıcaklık, yağış ve bunlara bağlı olarak iklimde meydana gelecek değişikliklerin farklı iklim senaryolarına göre değişimi belirlenmeye çalışılmıştır. Çalışma sonuçları, çalışmaya konu alanda 2050 yılından itibaren nemli alanların önemli ölçüde azalacağını ve kurak alanların oluşacağını göstermektedir.

Anahtar Kelimeler: İklim değişikliği, RCP senaryoları, De Martone, Emberger, Fındıklı Yaylası.

\section{Climate Type Changes That May Occur Due to The Global Climate Change in Kastamonu Province Findikli Plateau}

\begin{abstract}
Climate is a very important factor for living things and ecosystems all over the world. It is known that the positive or negative impact of the climate on the world affects people directly or indirectly. In this process, determining the changes in climate parameters and climate types in advance is of great importance in terms of the measures that can be taken and being prepared for the process. In our study, RCP (Representative Concentration Pathways) scenarios were based on RCP 4.5 and RCP 8.5 scenarios, which are generally used in academic studies. De Martone, Emberger and Lang climate classes were used, and according to these climate classes, climate types were evaluated for today, 2050 and 2100, and comparisons were made between them, so it was tried to predict how temperature, precipitation and how the climate would change in the process. In the study, it was tried to determine the changes of temperature, precipitation and the changes in climate according to different climate scenarios until 2050 and 2100 in Findiklı plateau, which is one of the important cities of our country, Kastamonu province, Arac district. The results of the study show that the humid areas will decrease significantly and dry areas will occur in the study area from 2050 onwards.
\end{abstract}

Keywords: Climate change, RCP scenarios, De Martone, Emberger, Findikli Plateau. 


\section{Giriş}

Bugün neredeyse tüm klimatoloji uzmanları, dünyanın iklim sisteminin değişmesi üzerinde ortak bir görüşe vardılar. Doğal dengeyi bozan insanların çeşitli faaliyetlerinin gerekli önleyici tedbirler alınmadan devam etmesi halinde bu iklim değişikliklerinin yoğunlaşacağı ve küresel ısınmanın çok olumsuz olabilecek iklim değişikliğine yol açacağı açıkça belirtilmektedir. Çünkü insan kaynaklı nedenlerden dolayı, sera gazlarının birikmesi ve atmosferdeki partikül maddelerinin artması, doğal ortamın tahrip olması ve ozon tabakasının incelmesi küresel sıcaklıkta artışa neden olacaktır (Öztürk, 2002; Ertuğrul, vd., 2021).

Türkiye karmaşık bir iklim yapısına sahiptir. Özellikle küresel ısınmaya bağlı olarak görülebilecek bir iklim değişikliğinden en fazla etkilenecek ülkelerden birisi ülkemiz olduğu belirtilmiştir. Doğal olarak üç tarafı denizlerle çevrili, topografik ve orografik özellikleri sebebiyle, Türkiye farklı şekilde ve farklı boyutlarda etkilenecektir. Örneğin, Güneydoğu Anadolu ve İç Anadolu gibi kurağa yakın ve yarı kurak bölgeler çölleşme riskine bağlı olarak daha fazla tehdit altındayken, yeterli suya sahip olmayan yarı nemli Ege ve Akdeniz bölgeleri küresel iklim değişikliğinden daha fazla etkilenecektir (Öztürk, 2002; Turan, 2018; Çetin, 2020).

Meydana gelecek iklim değişiklikleri, tarımsal faaliyetlerde hayvan ve bitkilerin doğal yaşam alanlarında değişikliklere yol açacak, özellikle yukarıda belirtilen bölgelerimizde, su kaynakları bakımından önemli sorunlar ortaya çıkacaktır. Hemen hemen bütün klimatoloji uzmanlarının üzerinde birleştiği ortak nokta ise gelecekte olabilecek iklim değişikliğinin, atmosferdeki sera gazı emisyonlarındaki artıştan kaynaklanan küresel ısınmadan olacağ 1 şeklindedir (Öztürk, 2002, Çetin vd., 2018).

Son yüzyılda dünya ikliminde önemli değişiklikler meydana geldiği ve bu değişikliklerin ilerleyen yıllarda etkisini daha ciddi boyutlarda göstereceği ifade edilmektedir. Olası değişikliklerin mümkün olduğu kadar önceden ve doğru şekilde tahmin edilmesi, alınacak önlemlerin belirlenmesinde ve dolayısıyla meydana gelecek değişikliklerin olası yıkıcı etkilerinin azaltılmasında büyük önem taşımaktadır (Adıgüzel vd., 2020, Cantürk,2020).

Bu çalışmanın amacı, ülkemizin önemli şehirlerinden biri olan Kastamonu ili Araç ilçesine bağlı Fındıklı yaylasında 2050 ve 2100 yıllarına kadar, sıcaklık, yağış ve bunlara bağlı olarak iklimde meydana gelecek değişikliklerin farklı iklim senaryolarına göre değişimi belirlenmeye çalışılmıştır.

\section{Materyal ve Metot}

Çalışma Türkiye'nin kuzeyinde yer alan Kastamonu ili Araç ilçesi Fındıklı yaylası ve çevresinde gerçekleştirilmiştir. Araç ilçesi Türkiye'nin kuzeyinde, Karadeniz Bölgesi’nin Batı Karadeniz Bölümü’nde, Kastamonu-Karabük arasında kurulmuş 1878 km²'lik bir yerleşim birimidir. Araç'a yakın yerler; doğuda Kastamonu Merkez ve İhsangazi, batıda Safranbolu, kuzeyde Daday ve Eflani, güneyde Ilgaz ve Ovacık'tır (Şekil-1). Araç, Karadeniz Bölgesi’nin Batı Karadeniz Bölümü’nde Kastamonu iline bağlı bir ilçe merkezidir.

Kasaba, Kastamonu-Karabük yolu üzerinde ve Ilgaz dağlarından kaynağını alan Araç çayının kuzey kıyısında kurulmuştur. Deniz seviyesinden yüksekliği 641 metredir. İlçenin yüzölçümü $1880 \mathrm{~km}^{2}$, kasaba yüzölçümü ise 35 km²' dir. İklimin genel karakteri; ilçenin batı yönü genellikle açık olup bölge, Karadeniz ardı iklim bölgesine daha doğrusu geçiş iklim bölgesine girmektedir. Yazları sıcak, kışları karlı ve donludur. Yağış genellikle ilkbahar ve sonbaharda yağar. Bu yağış kışın kar şeklindedir. Kar, Kasım sonları ve Aralık aylarında yağmaya başlar. Bazı yerlerde 1-1,5 metreyi bulur. Genel olarak ilkbahar serin geçer. Serinlik bilhassa yüksek kısımlarda kendini daha iyi gösterir. Yılın sıcak günleri Temmuz ayı başında başlayıp, Ağustos ayı ortalarına kadar devam eder (URL-1, 2020). 


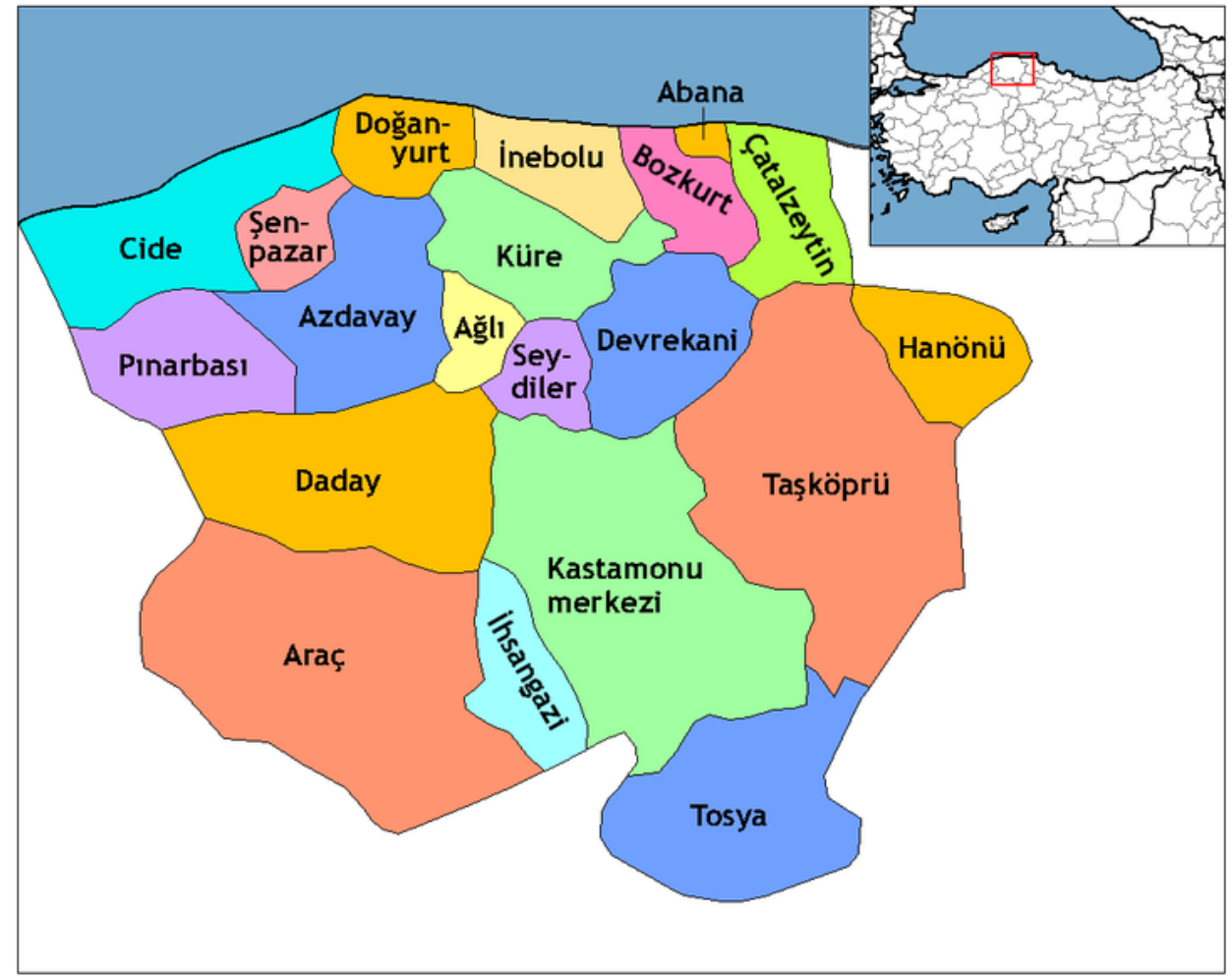

Şekil 1. Kastamonu ili ve ilçelerini gösterir harita (URL-1, 2020).

Gelecek iklim tiplerinin belirlenmesinde RCP 4.5 ve RCP 8.5 (Representative Concentration Pathways -Temsili Konsantrasyon Yolu) modeline ait Hadley Global Environment Model 2 - Earth System (HadGEM2-ES) küresel iklim modeli ile üretilmiş olan 2050 (2041-2060' ortalaması) ve 2100 (2061-2100' ortalaması) dönemlerine ait yukarıda verilen iklim parametrelerinin anomali değerleri baz alınarak üretilmiştir. Ayrıca meteroloji verilerini IDW yöntemi ile interpolasyon yapılmıştır (Akçakaya ve ark., 2015).

İklim modellerinin üretilmesi için yıllık ortalama sıcaklık ve yıllık ortalama toplam yağış, yıllık ortalama en yüksek sıcaklık, en sıcak ayın en yüksek sıcaklık ortalaması ve en soğuk ayın en düşük sıcaklık ortalaması parametreleri kullanılmıştır. Bu parametrelere dayanan ve araştırmada kullanılan Emberger (1932), De Martonne, (1926) ve Lang iklim sınıflandırma formülleri (Akman, 1990) aşağıda verilmiştir.

\section{Lang İklim Sınıflandırma Formülü :}

$\mathrm{L}=\mathrm{P} / \mathrm{Ta}$

P:Yıllık Ortalama Toplam Yağış (mm);

$\mathrm{Ta}=$ Yillık Ortalama Sicaklık $\left({ }^{\circ} \mathrm{C}\right)$

\section{De Martonne Formülü :}

$\mathrm{IM}=\mathrm{P} /(\mathrm{T}+10)$

P:Yıllık Ortalama Toplam Yağış(mm)

T:Yıllık Ortalama Sicaklık $\left({ }^{\circ} \mathrm{C}\right)$

\section{Emberger Formülü $\left({ }^{\circ} \mathrm{C}\right)$ :}

$\mathrm{IE}=\left((100 . \mathrm{P}) /\left(\mathrm{M}^{2}-\mathrm{m}^{2}\right)\right)$

M:En sicak ayın en yüksek sicaklık ortalaması

m:En soğuk ayın en düşük sıcaklık ortalaması

P:Yıllık ortalama toplam yağış

Yukarıda bahsedilen iklim parametreleri üzerine Lang, Emberger ve De-Martonne iklim indis formülleri CBS programları Arc GIS 10.5 yazılımı kullanılarak uygulanmıştır. Elde edilen raster harita Tablo 1'de verilen iklim sınıflandırma indislerine göre yeniden sınıflandırılarak (reclassify) iklim haritaları elde edilmiştir (Tablo 1.) 
Tablo 1. İklim İndisleri (Cantürk, 2020)

\begin{tabular}{ll}
\hline Lang iklim İndisi & \\
\hline $0-20$ & Çöl \\
$20,1-40$ & Kurak \\
$40,1-60$ & Yarı Kurak \\
$60,1-100$ & Yarı Nemli \\
$100,1-160$ & Nemli \\
\hline De Martonne İklim Indisi & \\
\hline $0-10$ & Kurak \\
$10,1-20$ & Yarı Kurak \\
$20,1-24$ & Akdeniz iklimi \\
$24,1-28$ & Yarı Nemli \\
$28,1-35$ & Nemli \\
$35,1-55$ & Çok Nemli \\
$>55$ & Aşırı Nemli \\
\hline Emberger İklim Indisi & \\
\hline$<30$ & Kurak \\
$30-50$ & Yarı Kurak \\
$50-90$ & Yarı Nemli \\
$>90$ & Nemli \\
\hline
\end{tabular}

Çalışma kapsamında RCP 4.5 ve RCP 8.5. senaryolarına göre 2050 ve 2100 yıllarında oluşacağı tahmin edilen sıcaklık ve yağış durumunun il genelindeki dağılımı kullanılarak De Martone, Emberger ve Lang iklim sınıflandırmalarına göre iklim tipleri belirlenmiş ve bu iklim tiplerinin hüküm süreceği alanlar haritalara işlenmiştir. Dolayısıyla sıcaklık ve yağış parametreleri ile De Martone, Emberger ve Lang iklim sınıflarına göre iklim tipleri günümüz, 2050 yılı ve 2100 yılı için değerlendirilmiş ve böylece sıcaklık, yağış ve bunlara bağlı olarak iklimin süreç içerisinde nasıl değişeceği tahmin edilmeye çalışılmıştır.

\section{Bulgular ve Tartışma}

\subsection{De martonne iklim sınıflandırmasına göre}

Çalışma alanı olan Araç ilçesi Fındıklı yaylası ve çevresinde De Martonne iklim sınıflandırması kullanılarak mevcut durum ve gelecekte (2050 ve 2100 yıllarında) olması muhtemel durum belirlenerek haritalandırılmış ve karşılaştırmalı olarak yorumlanmıştır. De Martonne iklim sınıflandırmasına göre günümüzdeki durum Şekil 2'de verilmiştir. 


\subsubsection{Günümüz}

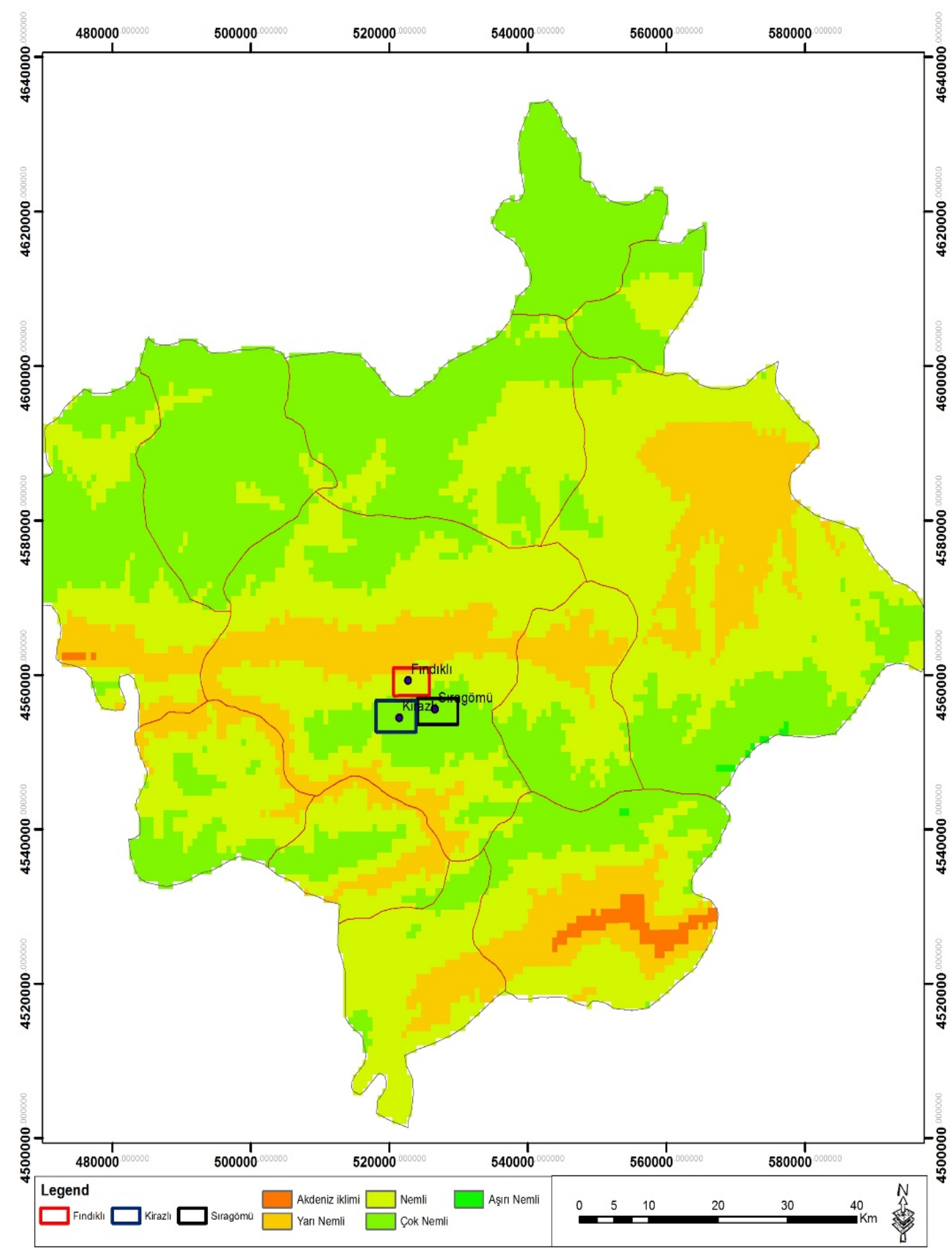

Şekil 2. De Martonne iklim sınıflandırmasına göre günümüz haritası.

De Martonne iklim sınıflandırmasına göre oluşturulan ve günümüzdeki durumu gösterir harita incelendiğinde Araç ilçesi Fındıklı yaylası ve çevresinin büyük bölümünün nemli alanlardan oluştuğu, ilin çok küçük bir alanının aşırı nemli alan olduğu görülmektedir.

Yapılan hesaplamalar sonucunda De Martonne iklim sınıflandırmasına göre Araç ilçesi Fındıklı yaylasında sadece \%0,09'unun aşırı nemli olduğu, \%0,75 inin akdeniz ikliminde olduğu, \%16,76'sının yarı nemli olduğu, \%39,93'ünün çok nemli olduğu ve \%42,47 sinin nemli olduğu belirlenmiştir. De Martonne iklim sinıflandırması ve RCP 4.5 senaryosuna göre belirlenen 2050 yılı durumunu gösterir harita, Şekil 3'de verilmiştir. 


\subsubsection{0 yıllındaki değişim (RCP 4.5)}

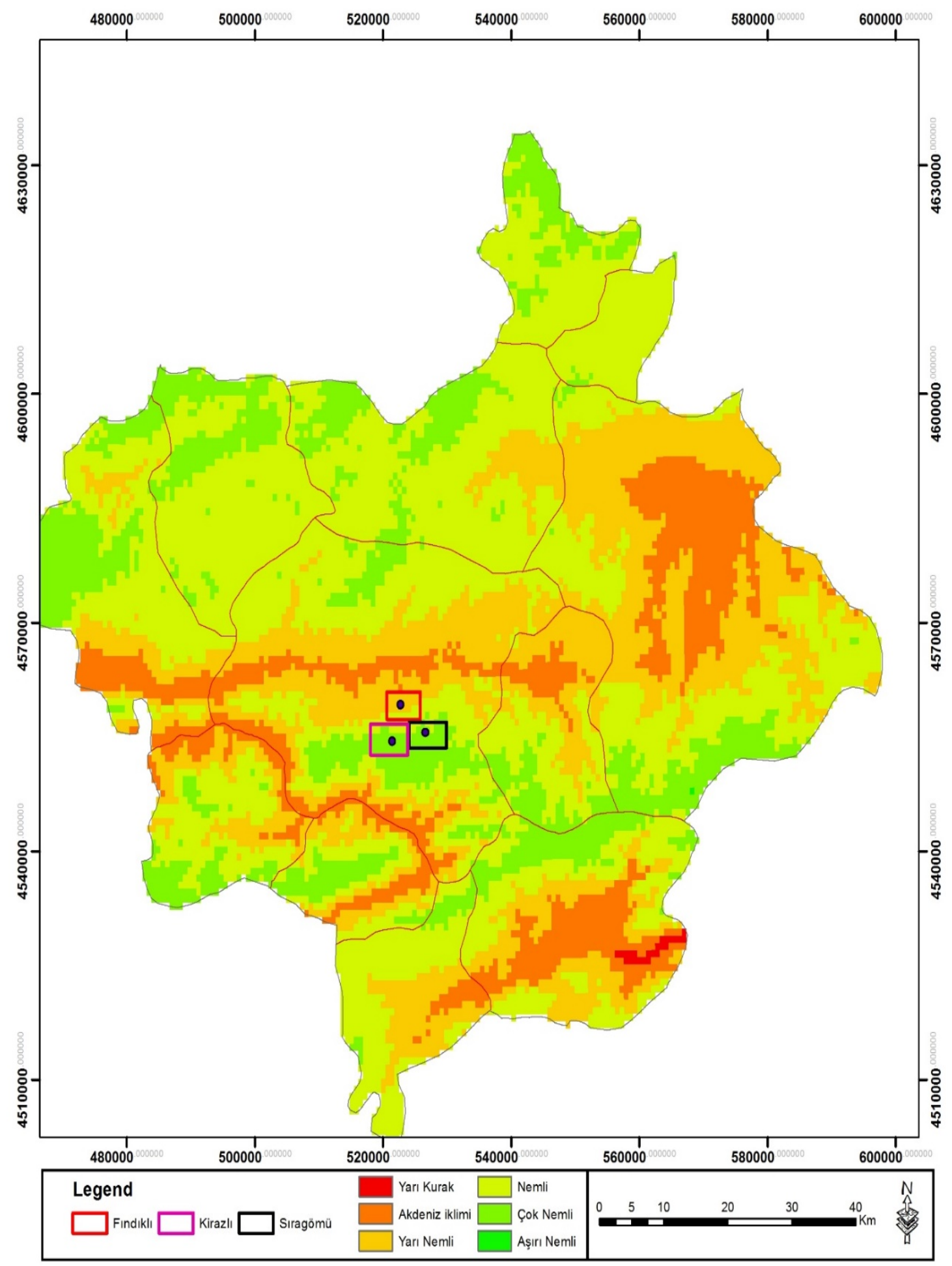

Şekil 3. De Martonne iklim sınıflandırması ve RCP 4.5 senaryosuna göre 2050 yılı haritası.

De Martonne iklim sınıflandırması ve RCP 4.5 senaryosuna göre belirlenen 2050 yılı durumunu gösterir harita incelendiğinde yarı kurak alanların günümüze göre önemli ölçüde arttığı görülmektedir. İlgili haritaya göre Araç ilçesi Fındıklı yaylası ve çevresinin 2050 yılında yaklaşık \%0,18'inin yarı kurak ve \%11,95'inin Akdeniz iklim tipine sahip olacağı, yarı nemli alanların oranının $\% 25,8$ 'e yükseleceği, nemli alanların oranının $\% 45,4$ olacağ ve çok nemli alanların oranının da \%0,01'e düşeceği öngörülmektedir. De Martonne iklim sınıflandırması ve RCP 8.5 senaryosuna göre belirlenen 2050 yılı iklim sınıfları durumunu gösterir harita, Şekil 4'de verilmiştir. 


\subsubsection{0 yılındaki değişim (RCP 8.5)}

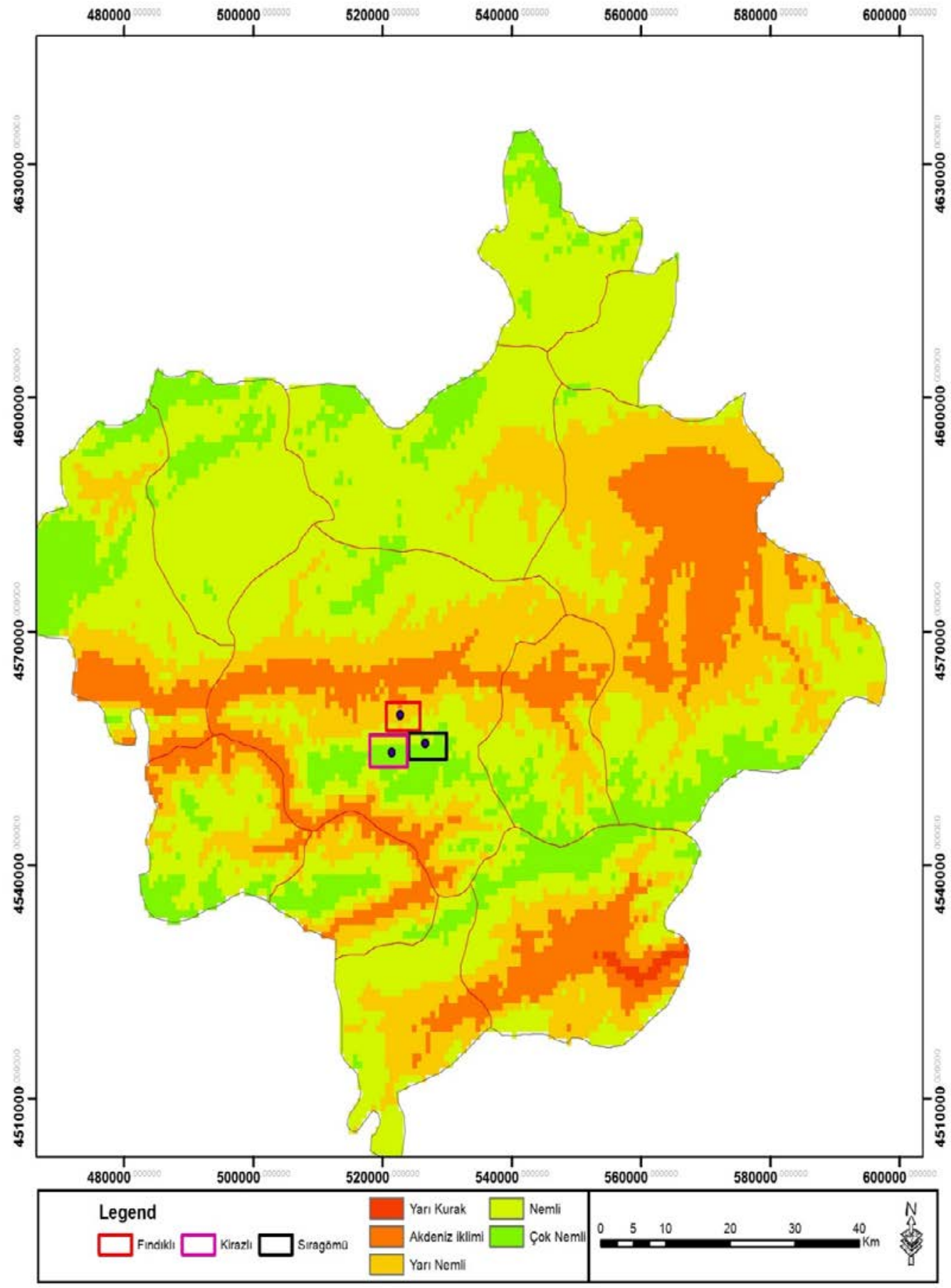

Şekil 4. De Martonne iklim sınıflandırması ve RCP 8.5 senaryosuna göre 2050 yılı.

De Martonne iklim sınıflandırması ve RCP 8.5 senaryosuna göre Araç ilçesi Fındıklı yaylası ve çevresi genelinde 2050 yılındaki durum incelendiğinde ilçede incelenen yaylalar genelinde günümüze göre yarı kurak alanların artacağı öngörülmektedir.

Yapılan hesaplamalara göre, Araç ilçesi Fındıklı yaylasında 2050 yılında yaklaşık \%0,26'sinin yarı kurak ve \%15,11'inin akdeniz iklim tipine sahip olacağı, yarı nemli alanların oranının \%26,06'e yükseleceği, nemli alanların oranının \% 45,55 olacağ 1 ve çok nemli alanların oranının da \%13,02'ye düşeceği belirlenmiştir. De Martonne iklim sınıflandırması ve RCP 4.5 senaryosuna göre belirlenen 2100 yılı iklim sınıfları durumunu gösterir harita, Şekil 5 'de verilmiştir. 


\subsubsection{0 yılındaki değişim (RCP 4.5)}

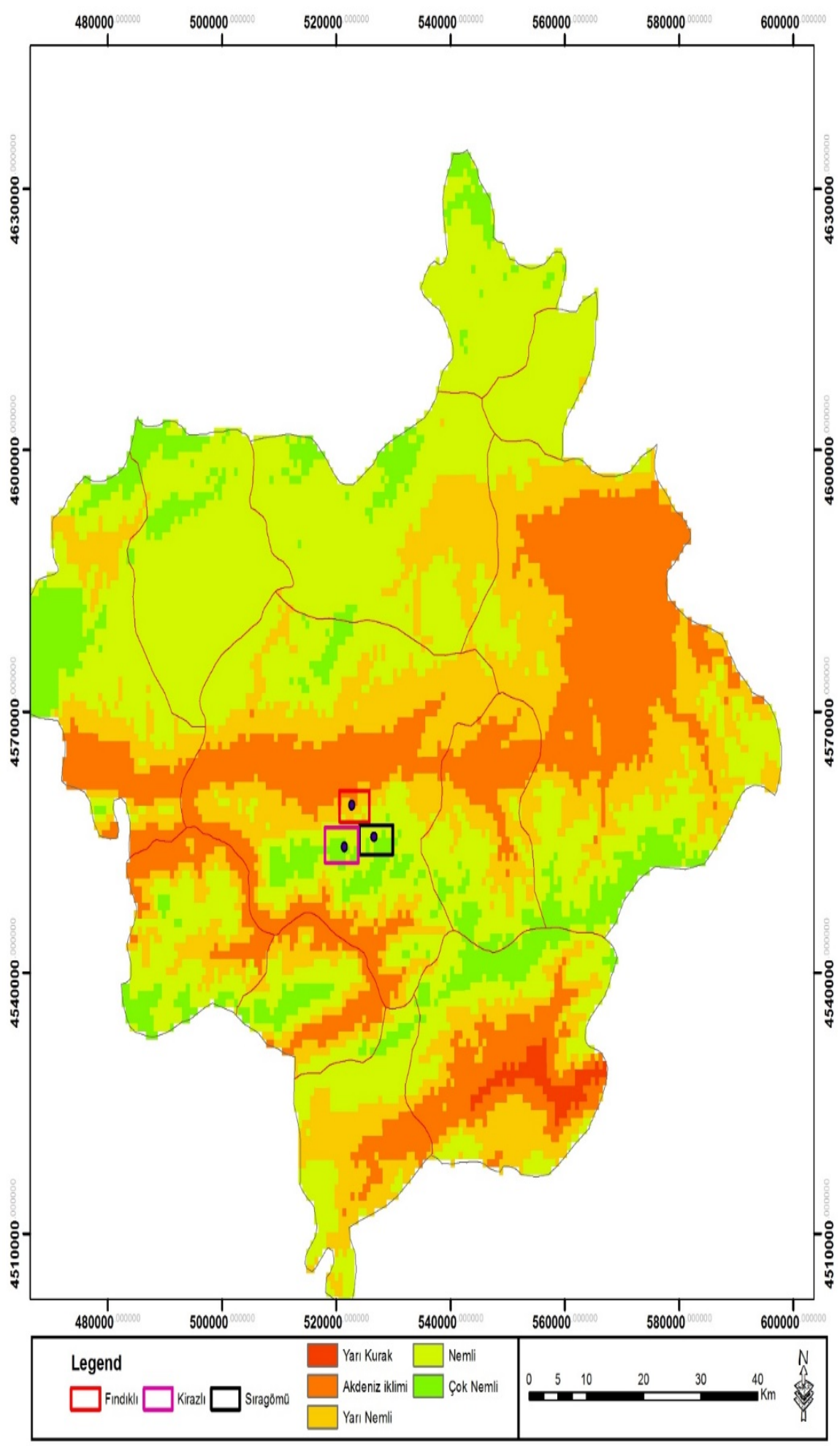

Şekil 5. De Martonne iklim sınıflandırması ve RC P4.5 senaryosuna göre 2100 yılı haritası.

Araç ilçesi fındıklı yaylası genelinde, De Martonne iklim sınıflandırması ve RCP 4.5 senaryosuna göre hazırlanan, 2100 yılındaki iklim sınıflarının durumu incelendiğinde Araç ilçesi yaylasının genelinde günümüze göre yarı kurak alanların artacağı öngörülmektedir. Yapılan hesaplamalar sonucunda Araç ilçesi Fındıklı yaylasının 2100 yılında yaklaşık \%0,7'sinin yarı kurak, \%21,05'inin akdeniz iklim tipinde, \%25,68'inin yarı nemli, \%42,99'unun nemli ve \%9,58'inin çok nemli iklim tipine sahip olacağı belirlenmiştir. De Martonne iklim sınıflandırması ve RCP 8.5 senaryosuna göre belirlenen 2100 yılı iklim sınıfları durumunu gösterir harita, Şekil 6' da verilmiştir. 


\subsubsection{0 yılındaki değişim (RCP 8.5)}

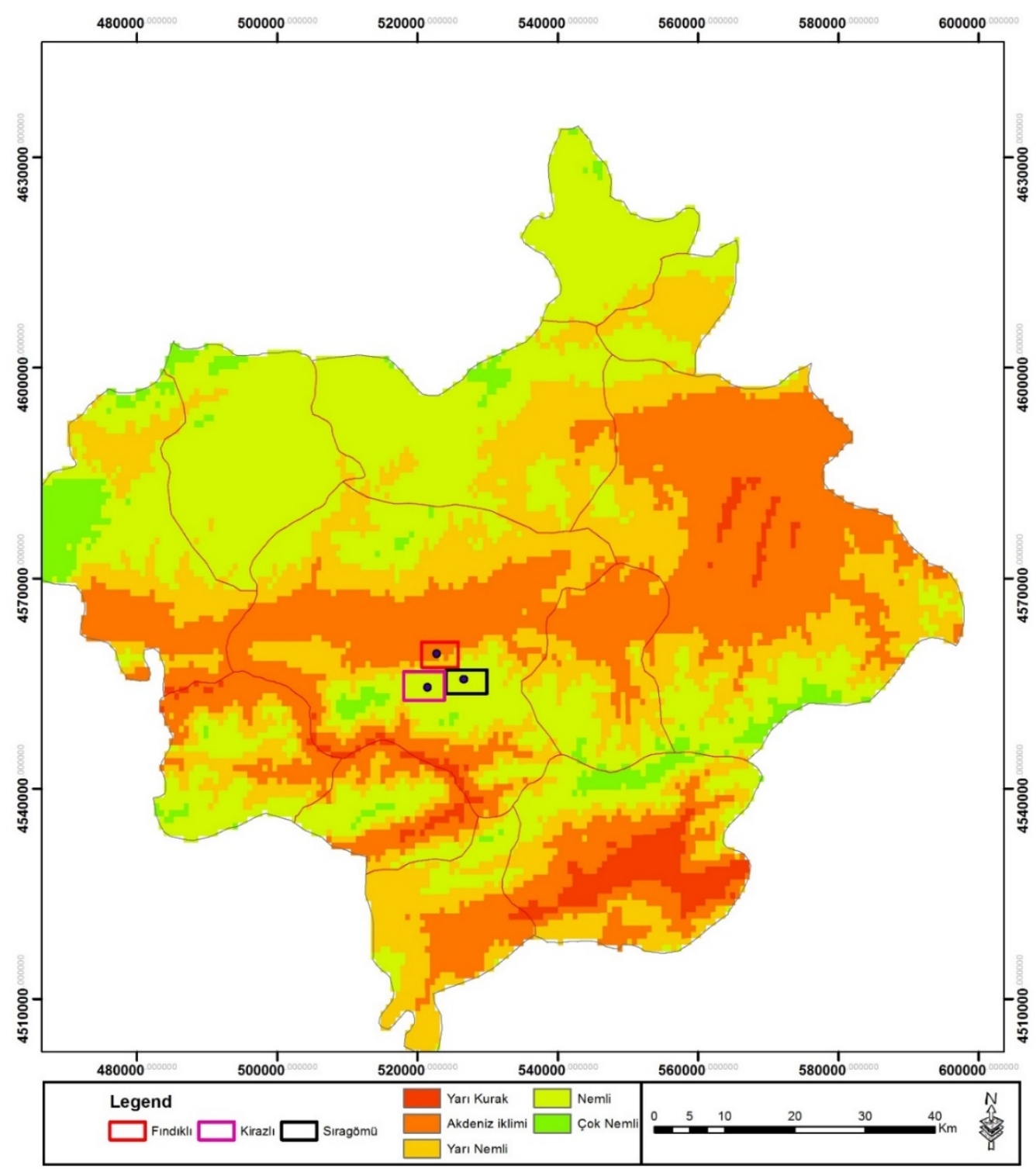

Şekil 6. De Martonne iklim sınıflandırması ve RCP 8.5 senaryosuna göre 2100 yılı haritası

RCP 8.5 senaryosuna göre 2100 yılında Araç ilçesi Fındıklı yaylası genelinde aşırı nemli alanın kalmayacağı, yarı kurak ve Akdeniz iklim kuşağındaki alanların artacağı yani genel olarak kurak iklim kuşaklarına doğru bir kayma olacağı öngörülmektedir. Yapılan hesaplamalara göre Araç ilçesi Fındıklı yaylasının 2100 yılında yaklaşık \%2,79'unun yarı kurak ve \%28,91'inin Akdeniz iklim tipine sahip olacağı, yarı nemli alanların oranının \%28,38 olacağı ve nemli alanların oranının \%35,98'e düşeceği, çok nemli alanların \%3,94 olacağı ve aşırı nemli alanların ise kalmayacağı belirlenmiştir.

\subsection{Emberger iklim sınıflandırmasına göre;}

\subsubsection{Günümüz}

Çalışma alanı olan Araç ilçesi Fındıklı yaylası ve çevresinde Emberger iklim sınıflandırması kullanılarak mevcut durum ile 2050 ve 2100 yıllarında olması muhtemel durum belirlenerek haritalandırılmış ve karşılaştırmalı olarak yorumlanmıştır. Emberger iklim sınıflandırmasına göre günümüzdeki durum Şekil 7'de verilmiştir. 


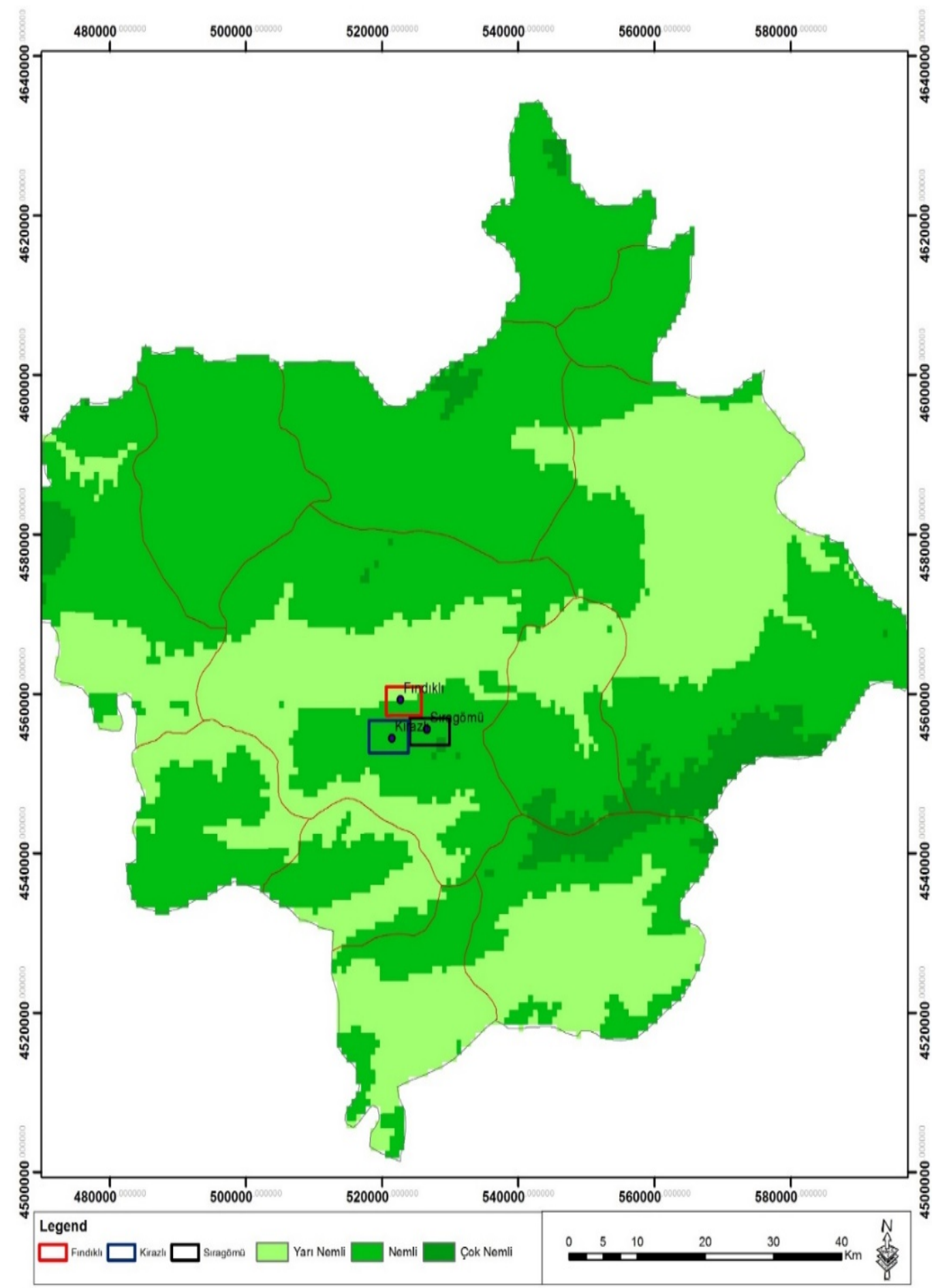

Şekil 7. Emberger iklim sınıflandırmasına göre günümüz haritası.

Emberger iklim sınıflandırmasına göre oluşturulan ve günümüzdeki durumu gösterir harita incelendiğinde Araç ilçesi Fındıklı yaylası ve çevresinin büyük bölümünün nemli alanlardan oluştuğu görülmektedir. Yapılan hesaplamalar sonucunda Emberger iklim sınıflandırmasına göre Fındıklı yaylası ve çevresinin sadece \%33,76'sının yarı nemli, \%61,09'unun nemli ve \%5,15'inin ise çok nemli olduğu belirlenmiştir. Emberger iklim sınıflandırması ve RCP 4.5 senaryosuna göre belirlenen 2050 yılı durumunu gösterir harita, Şekil 8'de verilmiştir. 


\subsubsection{0 yılındaki değişim (RCP 4.5)}

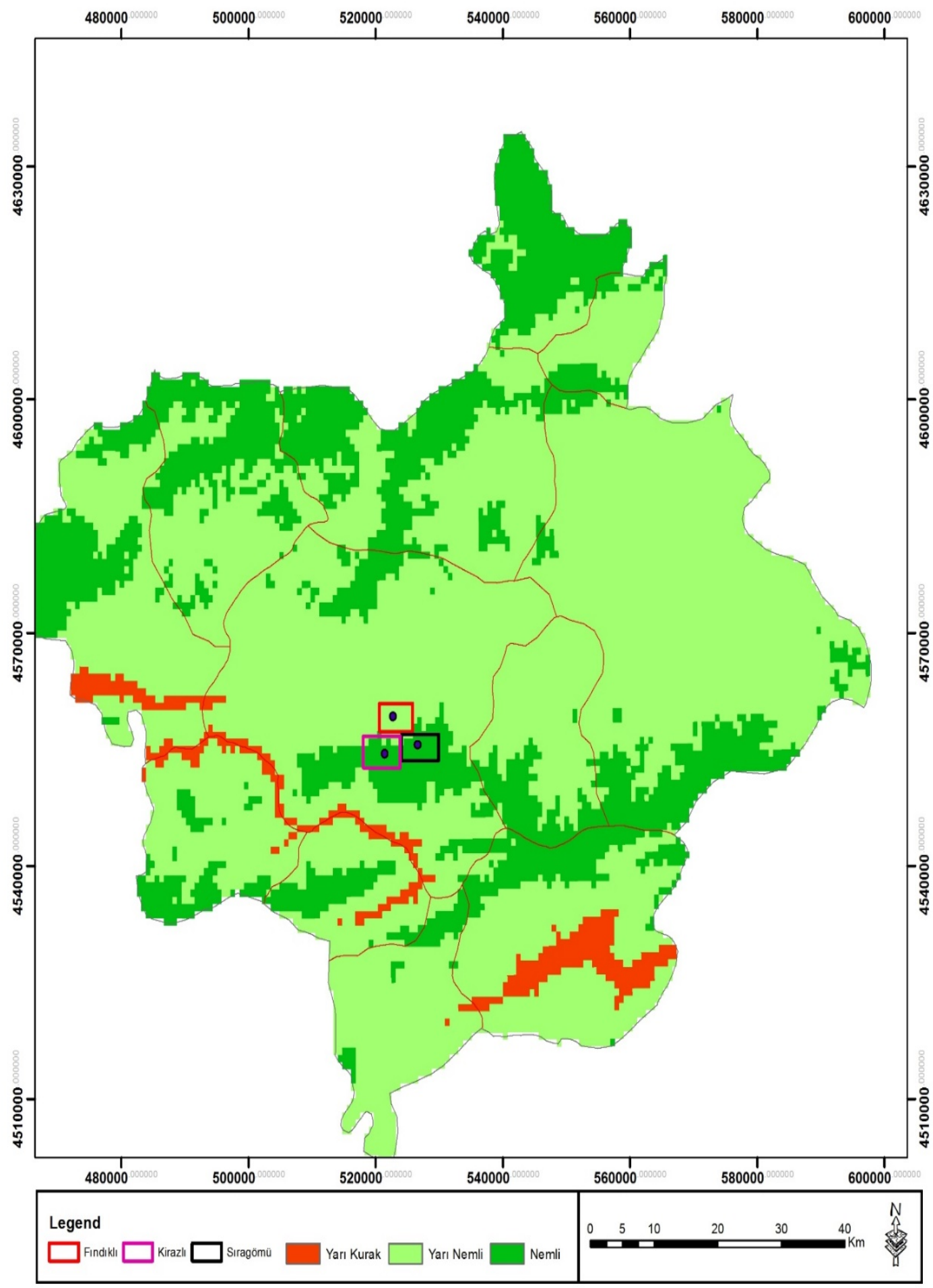

Şekil 8. Emberger iklim sınıflandırması ve RCP 4.5 senaryosuna göre 2050 yılı haritası.

Emberger iklim sınıflandırması ve RCP 4.5 senaryosuna göre belirlenen 2050 yılı durumunu gösterir harita incelendiğinde, günümüzde olmayan yarı kurak alanların oluştuğu ve çok nemli alanların kaybolduğu görülmektedir. İlgili haritaya göre Fındıklı yaylası ve çevresinin 2050 yılında yaklaşık \%70,94'ünün yarı kurak alan olacağı ve \%25,78'inin nemli alan olacağı öngörülmektedir. 2050 yılında yarı nemli alanların oranı \%33,76'dan \%70,94'e çıkarken nemli alanların oranının \%61,09'dan \%25,78'e düşeceği tahmin edilmektedir. 2050 yılında Fındıklı yaylası ve çevresinde yarı kurak alanlar ilin güneybatısında yer alırken nemli alanlar ilin kuzeybatısında ve kuzeyinde yer almaktadır. Emberger iklim sinıflandırması ve RCP 8.5 senaryosuna göre belirlenen 2050 yılı iklim sınıfları durumunu gösterir harita Şekil 9'da verilmiştir. 


\subsubsection{0 yılındaki değişim (RCP 8.5)}

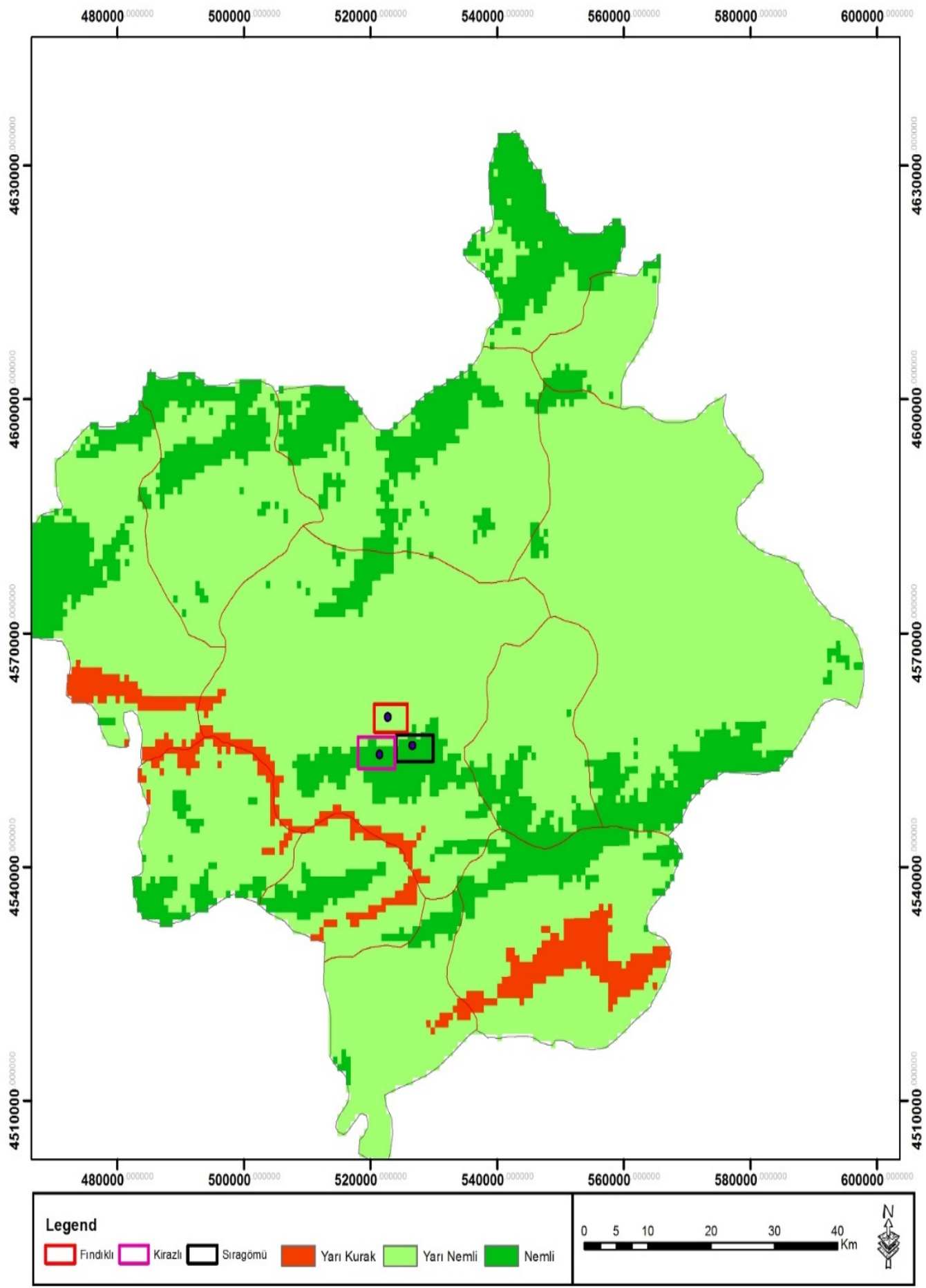

Şekil 9. Emberger iklim sınıflandırması ve RCP 8.5 senaryosuna göre 2050 yılı haritası.

Emberger iklim sınıflandırması ve RCP 8.5 senaryosuna göre Fındıklı yaylası ve çevresi genelinde 2050 yılındaki durum incelendiğinde Fındıklı yaylası ve çevresinin büyük bölümünün yarı nemli kuşağında kalacağı, günümüzde var olmayan yarı kurak alanların oluşacağı ve nemli alanların azalacağı öngörülmektedir. Yapılan hesaplamalara göre Fındıklı yaylası ve çevresinin 2050 yılında yaklaşık \%4,19'unun yarı kurak, \%75,7'sinin yarı nemli ve \%20,11'inin da nemli iklim sınıfında yer alacağı tahmin edilmektedir. Emberger iklim sınıflandırması ve RCP 4.5 senaryosuna göre belirlenen 2100 yılı iklim sınıfları durumunu gösterir harita, Şekil 10’ da verilmiştir. 


\subsubsection{0 yılındaki değişim (RCP 4.5)}

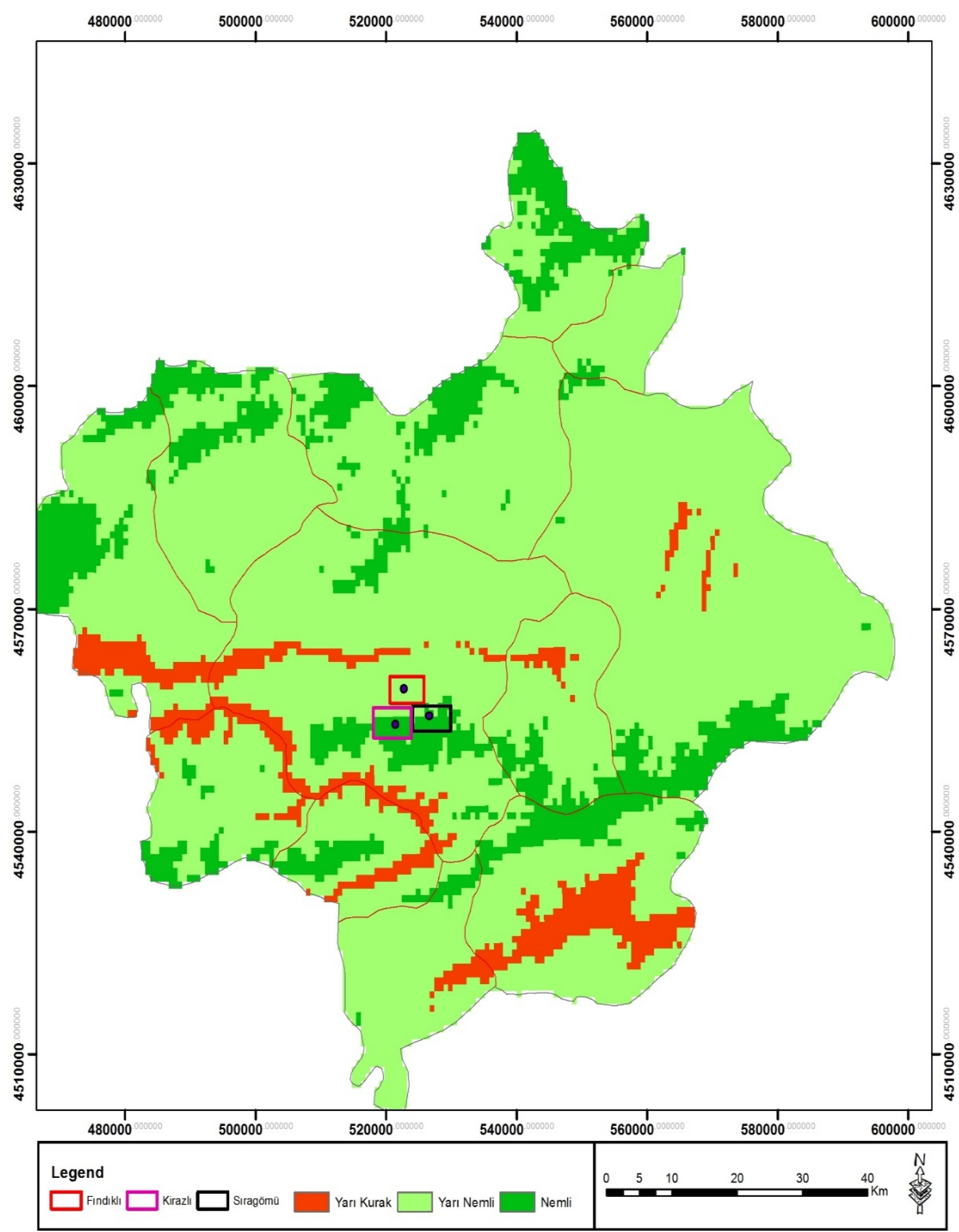

Şekil 10. Emberger iklim sınıflandırması ve RCP 4.5 senaryosuna göre 2100 yılı haritası.

Araç ilçesi Fındıklı yaylası ve çevresi genelinde Emberger iklim sınıflandırması ve RCP 4.5 senaryosuna göre hazırlanan, 2100 yılındaki iklim sınıflarının durumu incelendiğinde yayla ve çevresinde büyük bölümünün yine yarı nemli iklim kuşağında kalacağı, il genelinde 2050 yılına göre yarı kurak alanların artacağı, nemli alanların ise azalacağı öngörülmektedir. Yapılan hesaplamalar sonucunda yayla ve çevresinde 2100 yılında yaklaşık \%6,18'inin yarı kurak, \%77,97'sinin yarı nemli ve \%15,22'sinin ise nemli iklim tipine sahip olacağı belirlenmiştir. Emberger iklim sınıflandırması ve RCP 8.5 senaryosuna göre belirlenen 2100 yılı iklim sınıfları durumunu gösterir harita, Şekil 11'de verilmiştir. 


\subsubsection{0 yılındaki değişim (RCP 8.5)}

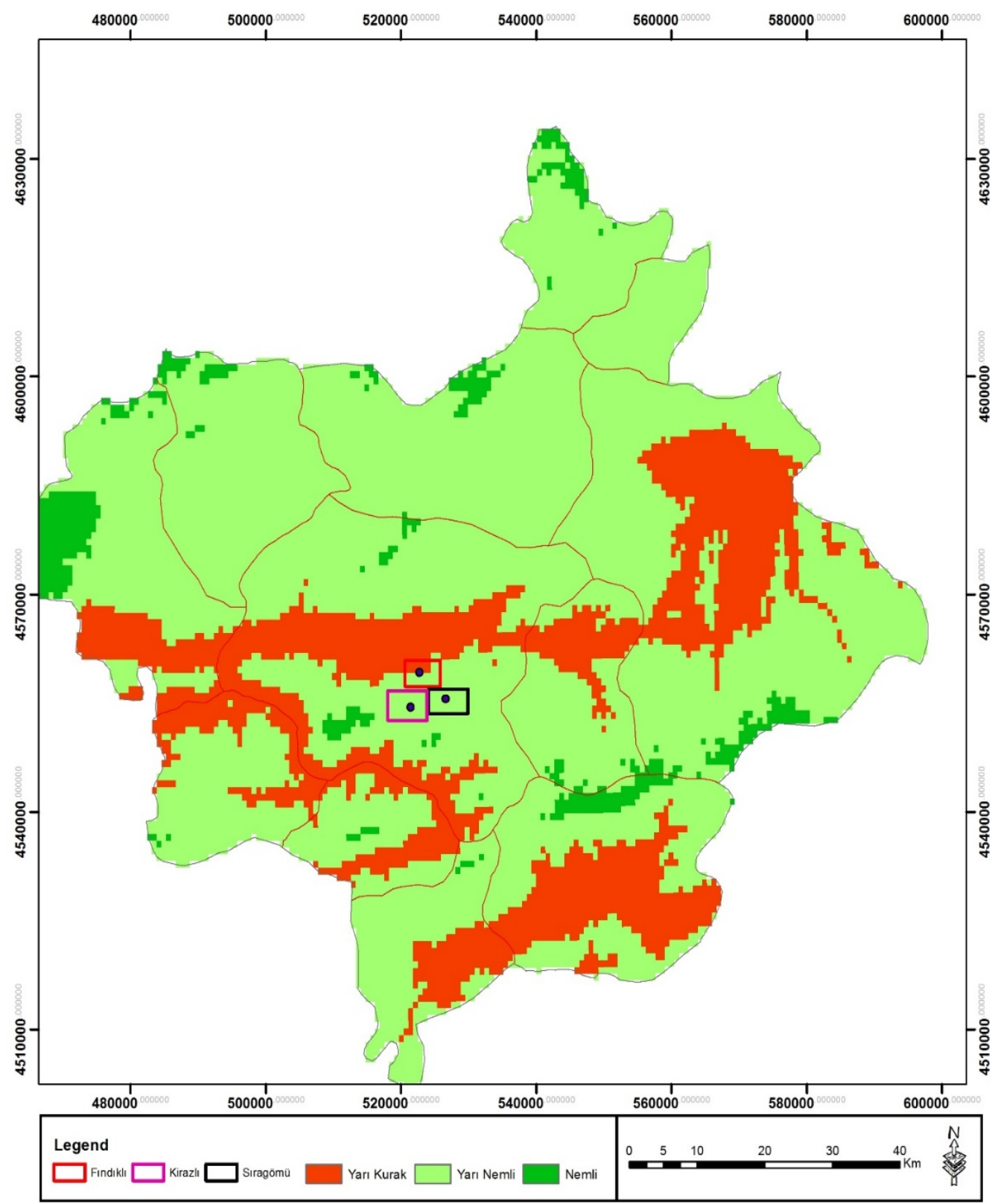

Şekil 11. Emberger iklim sınıflandırması ve RCP 8.5 senaryosuna göre 2100 yılı haritası.

RCP 8.5 senaryosuna göre 2100 yılında Araç ili Fındıklı yaylası ve çevresi genelinde nemli alanların iyice azalacağı ve yarı kurak alanların önemli ölçüde artacağı öngörülmektedir. Yapılan hesaplamalara göre yayla ve çevresinde 2100 yılında yaklaş1k \%21,62'sinin yarı kurak, \%73,89'unun yarı nemli ve \%4,49'unun da nemli iklim tipine sahip olacağı öngörülmektedir. Günümüzdeki durum ile kıyaslandığında durumun ne kadar ciddi olduğu anlaşılmaktadır. Günümüzde nemli alanların oranı \%61,09 iken 2100 y1lında \%4,49’a kadar gerilemekte, günümüzde \%33,76 olan yarı nemli alanların oranı \%73,89'a çıkmakta, daha da vahimi günümüzde yarı kurak alan bulunmazken 2100 yılında Araç ilçesi Fındıklı yaylası ve çevresi genelinin \%21,62'sinin yarı kurak alanlardan oluşacağı ayrıca günümüzde çok nemli alanların oranı \% 5,15 iken 2100 yılında çok nemli alanların kaybolacağı tahmin edilmektedir.

\subsection{Lang iklim sınıflandırmasına göre}

\subsubsection{Günümüz}

Çalışma alanı olan Araç ilçesi fındıklı yaylasın' da Lang iklim sınıflandırması kullanılarak mevcut durum ve 
gelecekte (2050 ve 2100 yıllarında) olması muhtemel durum belirlenerek haritalandırılmış ve karşılaştırmalı olarak yorumlanmıştır. Lang iklim sınıflandırmasına göre günümüzdeki durum Şekil 12'de verilmiştir.

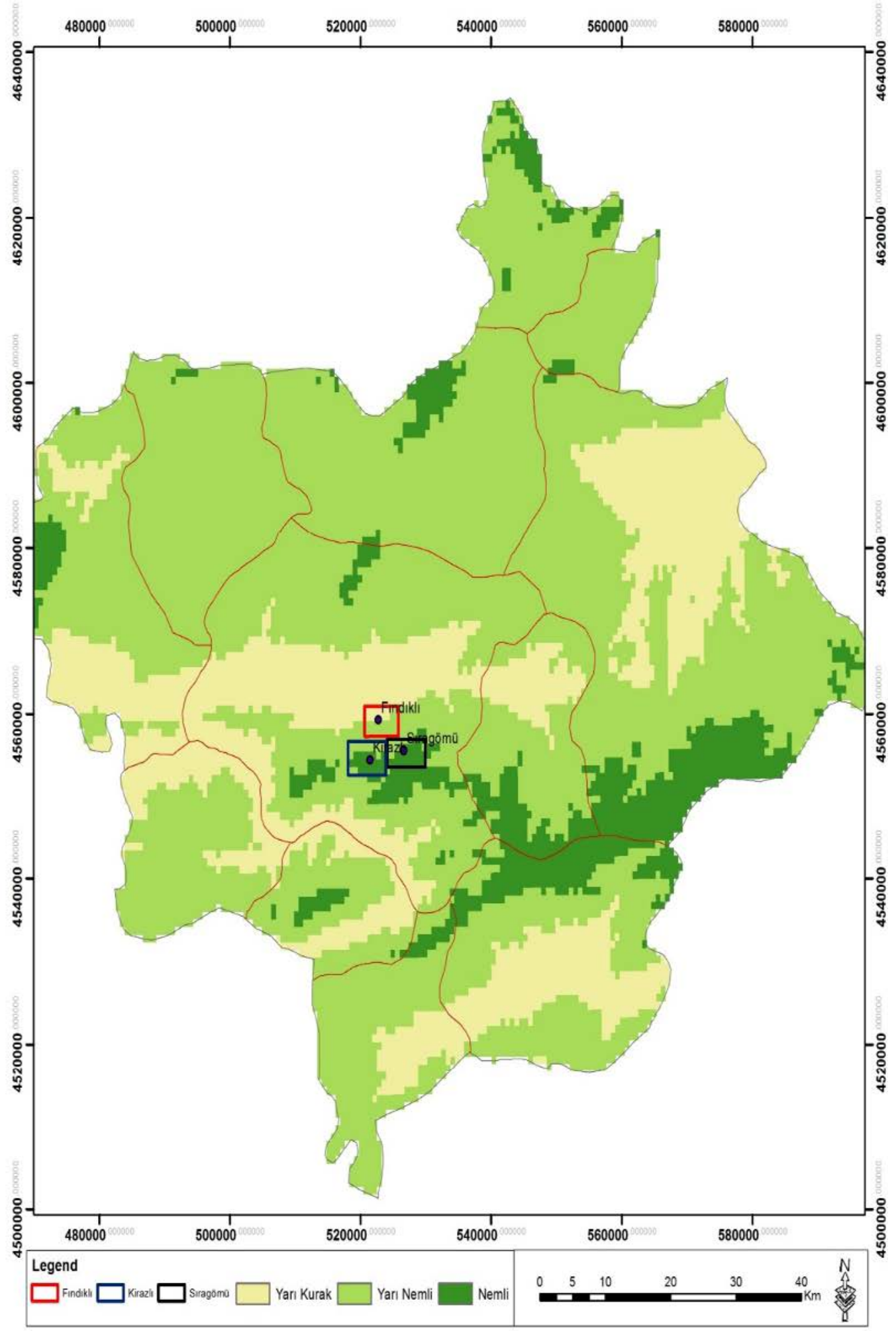

Şekil 12. Lang iklim sınıflandırmasına göre günümüz haritası.

Lang iklim sınıflandırmasına göre oluşturulan ve günümüzdeki durumu gösterir harita incelendiğinde Araç ilçesi findıklı yaylasının büyük bölümünün yarı nemli alanlardan oluştuğu görülmektedir. Yapılan hesaplamalar sonucunda Lang iklim sınıflandırmasına göre yayla ve çevresinin yaklaşık \%22,57'sinin yarı kurak, \%67,3'ünün yarı nemli ve \%10,13’ünün çok nemli olduğu belirlenmiştir. Lang iklim sınıflandırması ve RCP 4.5 senaryosuna göre belirlenen 2050 yılı durumunu gösterir harita, Şekil 13'de verilmiştir. 


\subsubsection{0 yılındaki değişim (RCP 4.5)}

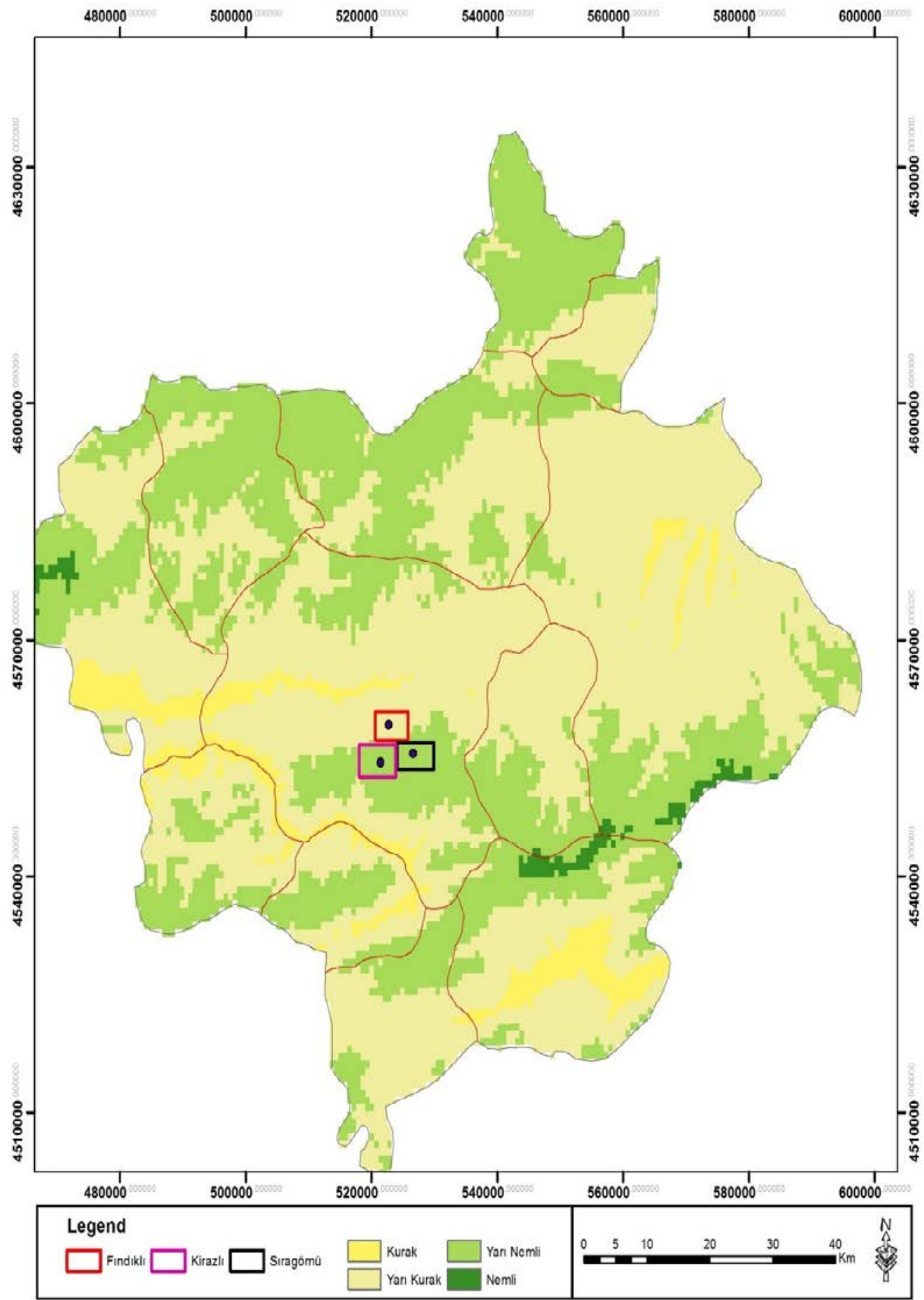

Şekil 13. Lang iklim sınıflandırması ve RCP 4.5 senaryosuna göre 2050 yılı haritası.

Lang iklim sinıflandırması ve RCP 4.5 senaryosuna göre belirlenen 2050 yılı durumunu gösterir harita incelendiğinde günümüzde olmayan kurak alanların oluştuğu, nemli alanların oranının ise neredeyse 10 kat daha çok gerilediği görülmektedir.

İlgili haritaya göre Araç ilçesi Fındıklı yaylası ve çevresinin 2050 yılında yaklaşık \%56,94'ünün yarı kurak alanlardan oluşacağı, \%36,21'inin yarı nemli alanlardan, nemli alanların oranının \%1,29'a düşeceği ve kurak alanların \%5,56 olacağı öngörülmektedir. 2050 yılında yayla ve çevresinde genel olarak doğu ve batı bölgelerinin daha kurak olacağı söylenebilir. Lang iklim sınıflandırması ve RCP 8.5 senaryosuna göre belirlenen 2050 yıl1 iklim sınıfları durumunu gösterir harita, Şekil 14'de verilmiştir. 


\subsubsection{0 yılındaki değişim (RCP 8.5)}

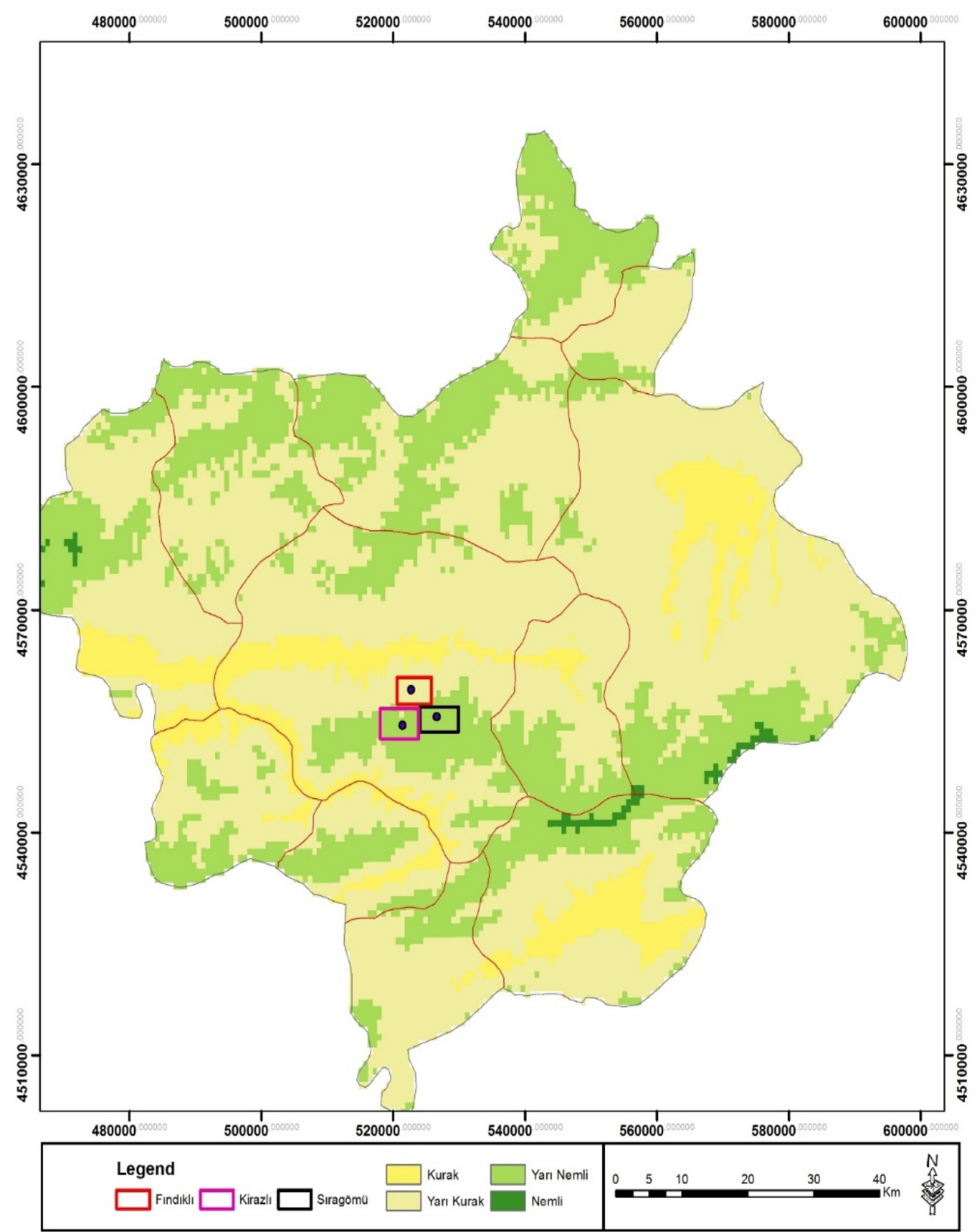

Şekil 14. Lang iklim sınıflandırması ve RCP 8.5 senaryosuna göre 2050 yılı haritası.

Lang iklim sınıflandırması ve RCP 8.5 senaryosuna göre Araç ilçesi Fındıklı yaylası ve çevresi genelinde 2050 yılındaki durum incelendiğinde yayla çevresinin büyük bölümünün yarı kurak iklim kuşağında kalacağı, il genelinde günümüzde olmayan kurak alanların oluşacağı görülmektedir.

Yapılan hesaplamalara göre yayla ve çevresinin 2050 yılında yaklaşı \% \%9,81'inin kurak ve \%61,44'ünün yarı kurak alanlar olacağı, nemli alanların oranının ise \%0,69'a düşeceği belirlenmiştir. Lang iklim sınıflandırması ve RCP 4.5 senaryosuna göre belirlenen 2100 yılı iklim sınıfları durumunu gösterir harita, Şekil 15' de verilmiştir.

\subsubsection{0 yılındaki değişim (RCP 4.5)}

Araç ilçesi fındıklı yaylası genelinde Lang iklim sınıflandırması ve RCP 4.5 senaryosuna göre hazırlanan, 2100 yılındaki iklim sınıflarının durumu incelendiğinde yayla ve çevresinde günümüzde olmayan ancak 2050 yılında oluşacağı tahmin edilen kurak alanların oranının artacağı tahmin edilmektedir. Yapılan hesaplamalara göre bu alanların oranı yaklaşık \%14,65 olacağı tahmin edilmektedir. 


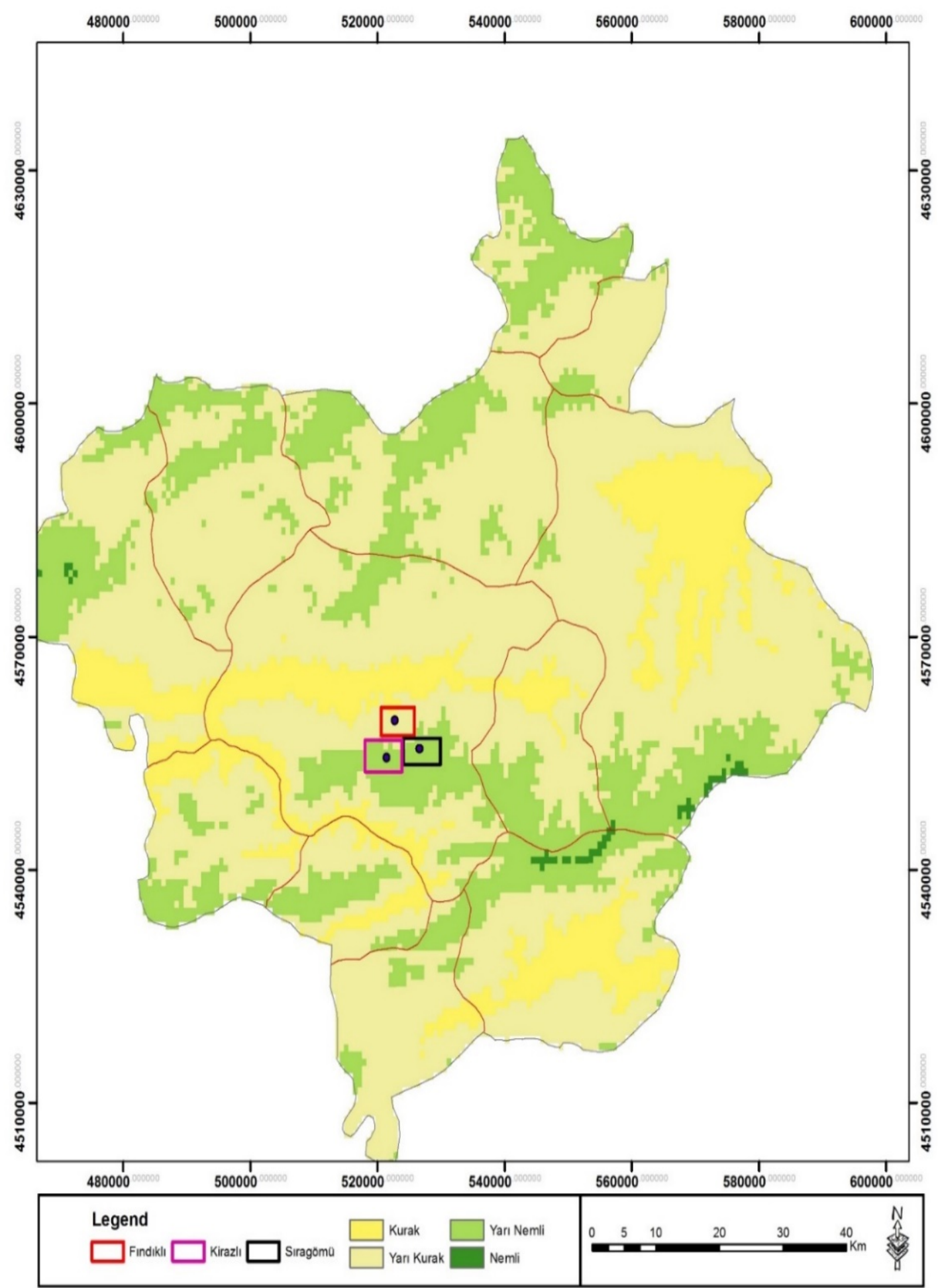

Şekil 15. Lang iklim sınıflandırması ve RCP 4.5 senaryosuna göre 2100 yılı haritası.

2100 yılında \%62,03 yarı kurak iklim kuşağının, \%22,84 yarı nemli ve \%0,48 nemli iklim kuşağının olacağı öngörülmektedir. Lang iklim sınıflandırması ve RCP 8.5 senaryosuna göre belirlenen 2100 yılı iklim sınıfları durumunu gösterir harita, Şekil 16’da verilmiştir.

\subsubsection{0 yılındaki değişim (RCP 8.5)}

RCP 8.5 senaryosuna göre 2100 yılında yayla ve çevresi genelinde nemli alanın hemen hemen kalmayacağı, il yüzölçümünün sadece \%0,03 'ünde nemli iklim kuşağının hakim olacağı belirlenmiştir. Yapılan hesaplamalara göre 2100 yılında yayla ve çevresinde yaklaşık \%62,3'ünün yarı kurak, \%9,46'sının yarı nemli ve \%0,03'ünün nemli 
iklim tipine sahip olacağı belirlenmiştir. Günümüzde bulunmayan kuraklık seviyesinin 2050 yılında \%9,81 iken 2100 yılında bu oranın \%28,21 seviyesine çıkması tahmin edilmektedir.

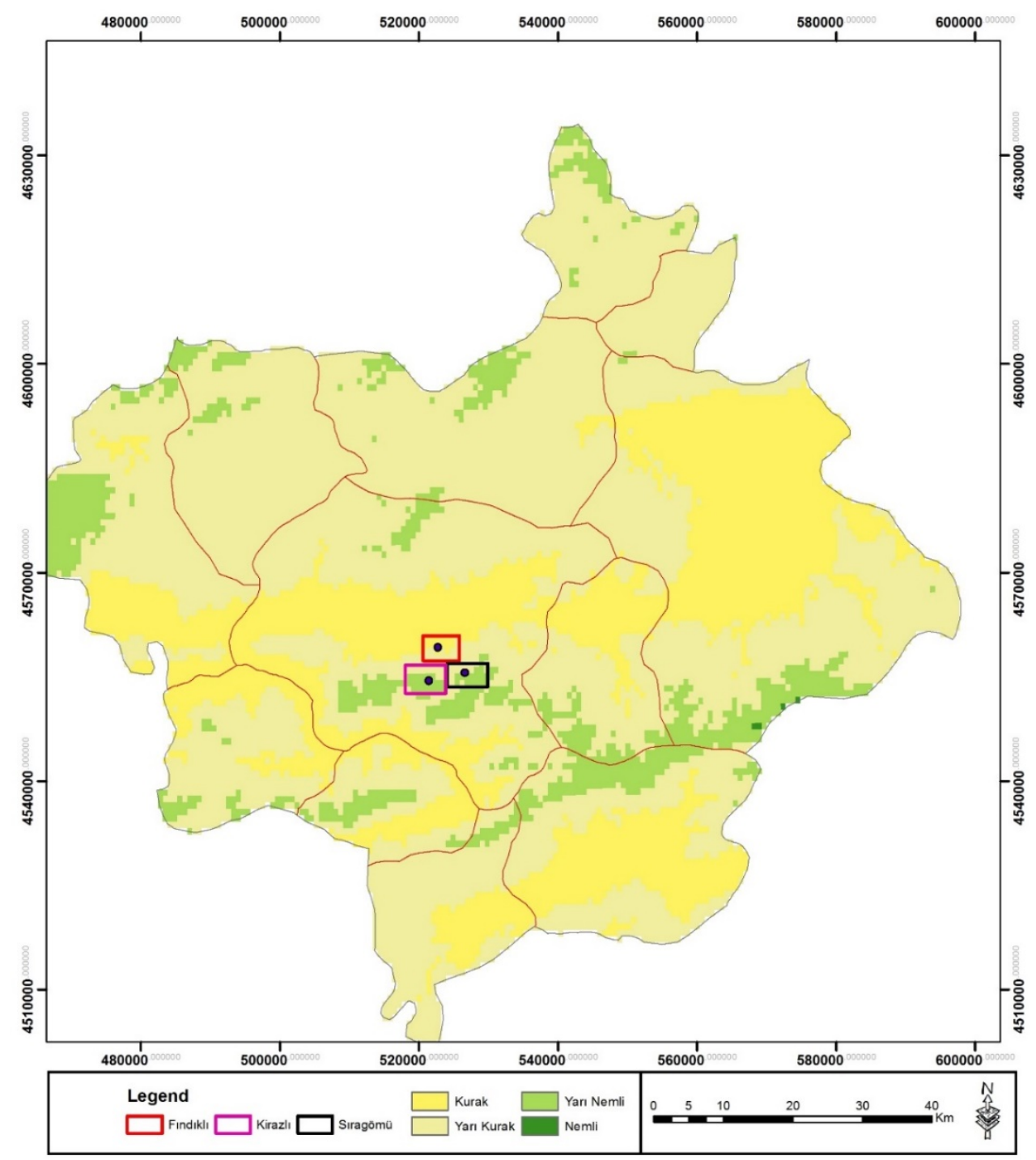

Şekil 16. Lang iklim sınıflandırması ve RCP 8.5 senaryosuna göre 2100 yılı haritası.

\subsection{Tartışma}

Çalışma sonuçlarına göre; gelecek yıllarda Araç ilçesi Fındıklı yaylası ve çevresinde RCP 4.5 senaryosu ve De Martonne iklim sınıflandırmasına göre günümüzde aşırı nemli alanlar görülürken 2050 yılında aşırı nemli alanların yok denecek kadar azalacağı, 2100 yılında ise aşırı nemli alanların kalmayacağı ve çok nemli alanların miktarının oldukça azalacağı, aynı zamanda da 2050 ve 2100 yıllarında yarı kurak alanların oluşacağı görülmüştür. Emberger iklim sınıfı ve RCP 4.5 senaryosuna göre 2050 ve 2100 yıllarında günümüzde bulunan çok nemli alanların yok olacağı ve günümüzde bulunmayan yarı kurak alanların oluşacağı tahmin edilmektedir. Lang iklim sınıfı ve RCP 4.5 senaryosuna göre 2050 ve 2100 yıllarında yayla ve çevresinde yarı kurak iklimin hüküm süreceği ve yıllar geçtikçe bu oranın artacağı tahmin edilmektedir. Yine aynı iklim sınıfına göre günümüzde görülmeyen kurak iklimin 2050 ve 2100 yıllarında bu bölgede görüleceği ve 2050 yılındaki oranı \%5,56 iken 2100 yılında bu oranın $\% 14,65$ olacağı tahmin edilmektedir.

Bir diğer senaryo olan RCP 8.5 senaryosuna göre De Martonne iklim sınıflandırmasında günümüzde aşırı nemli alanlar görülürken, 2050 ve 2100 yıllarında yarı kurak alanların oluşacağı ve aşırı nemli alanların ve çok nemli alanların seviyesinin gerileyeceği tahmin edilmektedir. Emberger iklim sınıfı ve RCP 8.5 senaryosuna göre günümüzde bulunan çok nemli alanların 2050 ve 2100 yıllarında yok olacağı, nemli alanların seviyesinin günümüzde \%61,09 iken 2100 yılında \%4,49'a gerileyeceği ve günümüzde bulunmayan yarı kurak alanların oluşacağı tahmin edilmektedir. Lang iklim sınıfı ve RCP 8.5 senaryosuna göre günümüzde bölgede yarı nemli 
iklim kuşağı hüküm sürerken 2100 yılında yarı kurak iklim kuşağının bölgede hüküm süreceği öngörülmektedir. Günümüzde bulunmayan kurak alanların oluşacağı ve 2100 yılına kadar bu alanların seviyesinin artacağı düşünülmekte, nemli alanların oranının 2100 yılına kadar neredeyse yok olacak seviyede düşeceği tahmin edilmektedir.

Genel olarak bakıldığında günümüz ve 2050-2100 yıllarındaki iklimde farklılaşmanın olduğu dikkat çekmektedir. Çalışma alanında iklim nemliden yarı kurak ve kurağa doğru değiştiği belirlenmiştir. Benzer çalışmalardan birinde, kullanılan bütün senaryolar ve iklim sinıflandırma modellerine göre 2050 yılında Samsun il genelinde sıcaklık ortalamasının artacağı, yağış miktarının azalacağı ve buna bağlı olarak iklim tipinin nemli iklimden karasal iklim tipine doğru kayacağını belirtilmiş̧tir. 2070 yılında ise bu değişikliklerin daha da fazla kendini göstereceği ifade edilmiştir (Cantürk, 2020).

Mersin il genelinde sıcaklık, yağış ve bunlara bağlı olarak iklim tiplerinin önemli ölçüde değişeceği ifade edilmiştir. Günümüzde $-0,4{ }^{\circ} \mathrm{C}$ ile $19^{\circ} \mathrm{C}$ arasında değişen sıcaklığın, RCP 8.5 senaryosuna göre 2070 yılında il genelinde 4,9 ${ }^{\circ} \mathrm{C}$ ile $24{ }^{\circ} \mathrm{C}$ arasında değişeceği yani sıcaklık değişim aralığında $5{ }^{\circ} \mathrm{C}$ civarında bir artış olacağını, yağış rejiminin değişeceği, iklim tiplerinin kurak iklim tiplerine doğru kayacağının tahmin edildiği belirtilmiştir (Çetin, 2020).

Küresel iklim değişikliğinin bütün dünyada önemli ve yıkıcı değişikliklere sebep olabileceği çok sayıda çalışmada dile getirilmiştir (Piao vd., 2019; Zhou vd., 2019; Clarke vd., 2019; Bouras vd., 2019). Ülkemizin de bu süreçten en fazla etkilenen ülkelerden birisi olacağı tahmin edilmektedir (Turan, 2018).

Atmosferin yapısında sanayi faaliyetleri başta olmak üzere insan kaynaklı değişimlerin özellikle son yüzyılda ciddi boyutlara ulaştı̆̆ bildirilmektedir (Turkyilmaz vd., 2018a,b; Sevik vd., 2019b; Aricak vd., 2020). Bu değişimlerin yansıyan etkisi ise dünyanın ortalama sıcaklığındaki artış olduğu ifade edilmiştir. Geçtiğimiz 136 yılda en yüksek sıcaklıkların yaşandığı 10 yıl, 1998 yılı haricinde 2000'den sonra meydana geldiği belirtilmiştir (Vural, 2018).

Küresel iklim değişikliğinin canlılar ve ekosistemler üzerinde yıkıcı ve geri döndürülemez etkileri olabileceği, orman yangınları, kuraklık, seller, çölleşme ve erozyon gibi iklime bağlı doğal afetler ve ekolojik bozulma oranlarını artıracağı, en önemli etkilerinin ise sıcaklık artışı ve su kaynaklarının azalması olacağı ifade edilmiştir (Mukherjee vd., 2018; Dai vd., 2018; Lee vd., 2019).

Canlıların morfolojik, anatomik ve fenolojik karakterleri genetik yapı ile çevre şartlarının etkisi altında şekillendiği belirtilmiştir (Hrivnak vd., 2017; Cetin vd., 2020). Canlı yaşamının devamlılığının, çeşitli dış şartların uygun değer aralıklarında olması durumunda mümkün olduğu bildirilmiştir. Özellikle bitkilerin gelişiminde ve yeryüzüne yayılışlarında en etkili olan faktörler klimatik faktörler olduğu ifade edilmiştir (Yiğit vd., 2018; Ertugrul vd., 2019; Ozkazanc vd., 2019; Ozel vd., 2020). Klimatik faktörlerin en önemlilerinden olan yağış ve sicaklık değişimi ve özellikle kuraklığın artışı birçok canlı yaşamını olumsuz yönde etkileyeceği bildirilmiştir (Şevik ve Ertürk, 2015; Yigit vd., 2016; Tahir vd., 2019).

\section{Sonuç ve Öneriler}

Küresel iklim değişikliği bütün dünyada yıkıcı etkilerini hissettirecek bir süreç olmakla birlikte henüz bu sürecin yeterince anlaşılamadığı düşünülmektedir. Oysa bu sürecin öncelikle yavaşlatılması, sonrasında ise iyileştirilmesi ancak, küresel çapta alınacak önlemler ve uygulamalarla mümkündür. İklim değişikliğinin yaşam alanlarını, ekosistemleri, gıda arzını, ekonomiyi vb. bütün etkilerinin senaryolar ışığında belirlenip kamuoyu ile paylaşılması ve bu konudaki görünürlük faaliyetlerinin artırılması, konu hakkında bilinç düzeyinin artmasına katkıda bulunacaktır.

Bu süreçte türlerin en az düzeyde etkilenmesini sağlamak amacıyla öncelikle, gelecekteki olası değişimlerin bugünden tahmin edilmesi ve meydana gelebilecek değişikliklere göre önlemler alınması gerekmektedir. Örneğin, iklim değişikliğinin etkilerinin daha fazla etkileneceği alanlarda hem bugünkü hem de gelecekteki şartlara daha iyi uyum sağlayabilen türler ile karışı ormanlar kurulması iyi olacağı düşünülmektedir. Böylece en azından tür kayıpları oluşsa da ormanların devamlılı̆ının sağlanacağı ayrıca karışık ormanların pek çok etkene karşı daha dirençli olmasının avantaj sağlayacağı düşünülmektedir.

Ayrıca genetik çeşitliliğin yüksek düzeyde tutulması sağlanmalıdır. Türlerin dış etkenlere karşı dayanıklılığı, tür içi genetik çeşitliliğe bağlı olarak önemli ölçüde değişmektedir. Genetik çeşitlilik; gelecekte olması muhtemel ve bugünden tahmin edilemeyen tehditlere karşı en önemli savunma mekanizmalarındandır. Bundan dolayı ormanlarda genetik çeşitliliğin korunmasına azami dikkat gösterilmelidir. 
Sonuç olarak; benzer çalışmalar çeşitlendirilip artırılarak devam ettirilmeli, değişen iklim ve çevre şartlarına göre yeni modeller üretilerek gerçeğe en uygun senaryolar oluşturulmalıdır. Daha sonra bu senaryolar ışı̆̆ında olası değişimlere göre önlemler alınmalıdır. Türler için bugün uygun yetişme şartlarını taşımayan ancak, gelecekte uygun yetişme şartlarını taşıyacak alanlara türlerin göçünün suni yollarla yapılması önerilebilir. Gelecekteki ağaçlandırma stratejileri bu bilgiler ışığında şekillendirilmelidir. Yapılacak uygulamalarda yine hem biyolojik hem de genetik çeşitliliğin korunmasına azami dikkat gösterilmelidir.

\section{Kaynaklar}

1. Adiguzel, F., Cetin, M., Kaya, E., Simsek, M., Gungor, S., Sert, E. B. (2020). Defining suitable areas for bioclimatic comfort for landscape planning and landscape management in Hatay, Turkey. Theoretical and Applied Climatology, 139(3-4), 1493-1503.

2. Akçakaya, A., Sümer, U. M., Demircan, M., Demir, Ö., Atay, H., Eskioğlu, O., Gürkan, H., Yazıcı, B., Kocatürk, A., Şensoy, S., Bölük, E., Arabacı, H., Açar, Y., Ekici, M., Yağan, S., Çukurçayır, F. (2015). Yeni Senaryolar ile Türkiye İklim Projeksiyonları ve İklim Değişikliği. Ankara: T.C. Orman ve Su İşleri Bakanlığı, Araştırma Dairesi Başkanlığı, Klimatoloji Ş̧ube Müdürlüğü, Meteoroloji Genel Müdürlüğ̈̈ Matbaası.

3. Akman, Y. (1990). İklim ve Biyoiklim (1. Basım). Ankara: Palme Yayınları.

4. Aricak, B., Cetin, M., Erdem, R., Sevik, H., Cometen, H. (2020). The usability of Scotch pine (Pinus sylvestris) as a biomonitor for traffic-originated heavy metal concentrations in Turkey. Polish Journal of Environmental Studies, 29(2)

5. Bouras, E., Jarlan, L., Khabba, S., Er-Raki, S., Dezetter, A., Sghir, F., Tramblay, Y. (2019). Assessing the impact of global climate changes on irrigated wheat yields and water requirements in a semi-arid environment of Morocco. Scientific reports, 9(1), 1-14.

6. Cantürk, Ö. (2020). Samsun Da Bazı İklim Parametreleri Ve Kuraklık Durumunun Küresel Isınmaya Bağlı Olarak Değişimi (Doctoral dissertation, KASTAMONU ÜNIVERSITTESİ).

7. Cetin, M., Sevik, H., Yigit, N., Ozel, H. B., Aricak, B., Varol, T. (2018). The variable of leaf micromorphogical characters on grown in distinct climate conditions in some landscape plants. Fresenius Environmental Bulletin, 27(5), 3206-3211.

8. Cetin, M. (2020). The Changing of Important Factors in The Landscape Planning Occur Due to Global Climate Change in Temperature, Rain and Climate Types: A Case Study of Mersin City. Turkish Journal of Agriculture-Food Science and Technology, 8(12), 2695-2701.

9. Cetin, M., Sevik, H., Cobanoglu, O. (2020). Ca, Cu, and $\mathrm{Li}$ in washed and unwashed specimens of needles, bark, and branches of the blue spruce (Picea pungens) in the city of Ankara. Environmental Science and Pollution Research, 1-10.

10. Clarke, H., Tran, B., Boer, M. M., Price, O., Kenny, B., Bradstock, R. (2019). Climate change effects on the frequency, seasonality and interannual variability of suitable prescribed burning weather conditions in south-eastern Australia. Agricultural and Forest Meteorology, 271, 148-157.

11. Dai, A., Zhao, T., Chen, J. (2018). Climate change and drought: A precipitation and evaporation perspective. Current Climate Change Reports, 4(3), 301-312.

12. Ertugrul, M., Ozel, H. B., Varol, T., Cetin, M., Sevik, H. (2019). Investigation of the relationship between burned areas and climate factors in large forest fires in thecanakkaleregion. Environmental monitoring and assessment, 191(12), 737.

13. Ertugrul, M., Varol, T., Ozel, H. B., Cetin, M., Sevik, H. (2021). Influence of climatic factor of changes in forest fire danger and fire season length in Turkey. Environmental monitoring and assessment, 193(1), $1-17$.

14. Hrivnák, M., Paule, L., Krajmerová, D., Kulaç, Ş., Şevik, H., Turna, İ., Tvauri, I., Gömöry, D. (2017). Genetic variation in Tertiary relics: The case of eastern-Mediterranean Abies (Pinaceae). Ecology and evolution, 7(23), 10018-10030.

15. Lee, M. H., Im, E. S., Bae, D. H. (2019). A comparative assessment of climate change impacts on drought over Korea based on multiple climate projections and multiple drought indices. Climate dynamics, 53(1-2), 389-404.

16. Mukherjee, S., Mishra, A., Trenberth, K. E. (2018). Climate change and drought: a perspective on drought indices. Current Climate Change Reports, 4(2), 145-163.

17. Ozel, H. B., Donduran, B., Cakmakli, E., Sevik, H. (2020). Factors affecting success in natural regeneration works of cedar (Cedrus libani A. Rich.) In Kas region of Antalya. World Journal of Advanced Research and Reviews, 6(2), 054-059. 
18. Ozkazanc, N. K., Ozay, E., Ozel, H. B., Cetin, M., Sevik, H. (2019). The habitat, ecological life conditions, and usage characteristics of the otter (Lutra lutra L. 1758) in the Balikdami Wildlife Development Area. Environmental Monitoring and Assessment, 191(11), 645.

19. Öztürk, K. (2002). Küresel İklim Değişikliği ve Türkiyeye Olası Etkileri. Gazi Üniversitesi Gazi Eğitim Fakültesi Dergisi, 22(1).

20. Piao, S., Liu, Q., Chen, A., Janssens, I. A., Fu, Y., Dai, J., Zhu, X. (2019). Plant phenology and global climate change: Current progresses and challenges. Global change biology, 25(6), 1922-1940.

21. Sevik, H., Cetin, M., Ozturk, A., Yigit, N., Karakus, O. (2019b). Changes in micromorphological characters of Platanus orientalis L. leaves in Turkey. Applied Ecology and Environmental Research, 17(3), 5909-5921.

22. Şevik, H., Ertürk, N. (2015). Effects of drought stress on germination in fourteen provenances of Pinus brutia Ten. seeds in Turkey. Turkish Journal of Agriculture-Food Science and Technology, 3(5), $294-299$.

23. Tahir, A., Qadir, M., Saif, R., Sattar, S., Tahir, S. (2019). Morphological and Yield Response of Pulses Against Drought Stress: A Review. Turkish Journal of Agriculture-Food Science and Technology, 7(2), 202208.

24. Turan, E. S. (2018). Turkey’s Drought Status Associated with Climate Change. Artvin Çoruh University Natural Hazards Application and Research Center Journal of Natural Hazards and Environment. 4(1), 6369, DOI: $10.213247 /$ dacd.357384

25. Turkyilmaz, A., Sevik, H., Cetin, M. (2018a). The use of perennial needles as biomonitors for recently accumulated heavy metals. Landscape and Ecological Engineering, 14(1), 115-120.

26. Turkyilmaz, A., Sevik, H., Isinkaralar, K., Cetin, M. (2018b). Using Acer platanoides annual rings to monitor the amount of heavy metals accumulated in air. Environmental monitoring and assessment, 190(10), 578.

27. URL-1 (2020). http://www.arac.bel.tr/content/cografya-107

28. Vural, Ç. (2018). Küresel İklim Değişikliği ve Güvenlik. Güvenlik Bilimleri Dergisi, Mayıs 2018,7 (1), 57 $-85$

29. Yigit, N., Sevik, H., Cetin, M., Kaya, N. (2016). Determination of the effect of drought stress on the seed germination in some plant species. Water stress in plants, 43-62.

30. Yiğit, N., Çetin, M., Şevik, H. (2018). The change in some leaf micromorphological characters of Prunus laurocerasus L. species by their habitat. Turkish Journal of Agriculture-Food Science and Technology, 6(11), 1517-1521.

31. Zhou, Y., Hartemink, A. E., Shi, Z., Liang, Z., Lu, Y. (2019). Land use and climate change effects on soil organic carbon in North and Northeast China. Science of the Total Environment, 647, 1230-1238. 